\title{
Who is a dangerous driver? Socio-demographic and personal determinants of risky traffic behavior
}

\author{
Aleksandra Peplińska ${ }^{A, B, D, E, F, G}$, Magdalena Wyszomirska-Góra ${ }^{B, D, E, F}$, Piotr Połomski ${ }^{B, C, E}$, \\ Marcin Szulc ${ }^{A, B, D, E, F}$ \\ Institute of Psychology, University of Gdansk, Gdansk, Poland
}

\section{BACKGROUND}

The aim of this study was to search for comprehensive socio-demographic and personal (personality and temperamental) determinants of risky on-the-road behavior. Based on the results of previous studies, we assumed that the main predictors of dangerous traffic behavior include: internal locus of control, sensation seeking, risk seeking and risk acceptance, as well as high self-esteem, a low level of reactivity combined with a high level of endurance and activity (which together determine a strong need for stimulation and a preference for hedonistic values); and among socio-demographic variables - age, gender, education and duration of having a driving license.

\section{PARTICIPANTS AND PROCEDURE}

The study included a group of 380 participants, aged between 19 and 61 years $(\mathrm{Me}=24)$. In order to verify the hypothesis, a battery of research tools measuring personality and temperamental variables was adopted, namely: the Formal Characteristics of Behavior - Temperament Questionnaire, Rotter I-E Scale, Risk Acceptance Scale, Stimulating-Instru- mental Risk Inventory, Scheler Value Scale, Zuckerman Sensation Seeking Scale and Rosenberg Self-Esteem Scale.

\section{RESULTS}

The dangerous driver syndrome was found to be promoted by high levels of experience and sensation seeking, low levels of tolerance to boredom and monotony, high need for stimulating risk and high risk acceptance, high self-esteem, a preference for hedonistic values coupled with aversion towards moral values, as well as low sensory sensitivity, and was especially visible among older men with short driving experience.

\section{CONCLUSIONS}

It can be concluded that both socio-demographic and psychological variables, such as temperament and personality, are significant predictors of dangerous traffic behavior.

\section{KEY WORDS}

reckless driving; risky traffic behavior; transport psychology; dangerous driver

Corresponding author - Aleksandra Peplińska, Ph.D., Institute of Psychology, University of Gdansk, 4 Bażyńskiego Str., 80-952 Gdansk, Poland, e-mail: a.peplinska@ug.edu.pl

AUthors' Contribution - A: Study design - B: Data collection - C: Statistical analysis - D: Data interpretation .

E: Manuscript preparation · F: Literature search · G: Funds collection

to Cite this ARTICle - Peplińska, A., Wyszomirska-Góra, M., Połomski, P., \& Szulc, M. (2015). Who is a dangerous driver? Socio-demographic and personal determinants of risky traffic behavior. Current Issues in Personality Psychology, 3(3), 149-158. 


\section{BACKGROUND}

Over the course of recent years, a progressive decrease in the number of road traffic accidents, including fatal ones, was observed in Poland and other European Union countries (www.msw.gov.pl). Regardless of this trend, the number of accidents is still appalling, however. In 2014, the number of road traffic accidents in Poland was 34 970, including 3202 fatalities and 42545 injured victims (www.statystyka.policja.pl). Since the problem continues to exist despite some systemic solutions aimed at increasing road safety, it should be a priority not only among the actions taken by the representatives of emergency services, politicians or practitioners, but also by scientists dealing with the issues of road safety. Driving under the influence of drugs or alcohol (Szulc, 2013), foolhardiness, speeding, aggression, and lack of cautiousness are among the most common causes of road traffic accidents (Bąk \& Bąk-Gajda, 2008). Yet their number is also determined by many socio-demographic traits of drivers, such as age, gender, education or the number of children (Bener et al., 2008; Donmez, Boyle, \& Lee, 2010; Krahé \& Fenske, 2002). Some of the most typical problems of older drivers are: lack of cautiousness, and overestimating one's own skills coupled with only scant consciousness of the fact that one's psychomotor functioning has deteriorated. Dangerous situations in road traffic are also caused because of decreased driving dynamics and a slow decision-making process (Rimmö \& Hakamies-Blomqvist, 2002). On the other hand, a wishful assessment of the situation, consciously flouting traffic rules or social norms, and overestimating one's driving skills are frequently recognized as causes of accidents involving young - and often inexperienced - drivers (Donmez et al., 2010). Results of previous studies dealing with these problems indicate that significant predictors of dangerous traffic behavior are not limited to socio-demographic factors, but also include an individual's psychological make-up, especially personality traits (Garrity \& Demick, 2001; Schreer, 2002), intellectual capacity (Arthur, Barret, \& Alexander, 1991; Shinar, 1978; Wyszomirska-Góra, 2013), and psychomotor functioning (Treffner \& Barrett, 2004), i.e. visual-motor coordination, reaction time, the ability to correctly estimate distance and speed, seeing in the dark, and headlight glare resistance. All these factors are focal points of transport psychology.

\section{A DANGEROUS DRIVER}

No clear profile of a dangerous driver has been established so far, although a number of previous studies on transport psychology attempted to achieve that. On one hand, this may result from a narrow range of studies which include only a limited range of drivers' personality traits, and, on the other, from the way respondents are selected: sampling prevents the results from being generalizable, and determining the criteria to classify a driver as a dangerous one is problematic, too. A vast majority of research studies have focused on drivers who not only pose a real threat to other road users, but who actually cause traffic accidents. Researchers try to both identify particular groups of drivers who can potentially make mistakes resulting in road accidents, and also explain some of the psychological phenomena that increase the probability of this happening (Waszkowska \& Garczarek, 2008). A number of psychological and social characteristics of accident perpetrators have been identified. According to Schaw and Sichel (1971), the accident rate increases when extreme extraversion is combined with sociopathic traits - this manifests in excessive self-concentration, aggressiveness, impulsiveness, irresponsibility, intolerance and challenging authorities. Thiffault and Bergeron (2003) found that extrovert drivers with a high need for stimulation can be more susceptible to monotonous conditions and thereby more prone to making mistakes while on the road. Other common traits of perpetrators of traffic accidents include auto-destructive tendencies, neuroticism, immaturity, emotionality, low stress resistance (Garrity \& Demick, 2001; Szmajke, 1992) and low self-control (Havârneanu \& Havârneanu, 2012). According to one hypothesis, the tendency to cause traffic accidents may be characteristic of A type individuals; however, this has never been confirmed in a satisfactory way in empiric research (Nabi et al., 2005). What is more, a relationship between road traffic accidents and some cognitive functioning disorders, especially attention problems, is postulated in the literature. Studies of older persons by McKnight and McKnight (1999) revealed significant relationships between dangerous driving and the prevalence of cognitive deficits in the areas of attention, short-term memory and quickness of perception. The above-mentioned psychomotor skills also seem important from the point of view of driving mechanical vehicles safely; however, this issue has not been satisfactorily addressed in the literature. According to McKnight and McKnight, a dangerous driving style typical of elderly drivers is associated with longer reaction times.

A question arises whether a person classified as a dangerous driver has to be a cause of an accident. Undoubtedly, an accident rate index is the most objective way to address this question. Nevertheless, we could label a dangerous driver anyone who poses a real threat in traffic, the potential negative consequences of which are prevented by emergency services or other road users. The number of road collisions, the number of traffic tickets for breaking traffic rules (especially speeding, overtaking on dou- 
ble white lines or on a pedestrian crossing), and finally driving under the influence of alcohol or drugs - all these factors increase the probability of causing an accident and therefore could be used as indicators of a dangerous driving style. Driving under the influence of illicit substances has been shown to negatively impact one's driving performance as well as general traffic safety (Havârneanu \& Havârneanu, 2012; Watling \& Freeman, 2011).

\section{PERSONAL DETERMINANTS OF RISKY ON-THE- ROAD BEHAVIOR}

Having analyzed both the literature of the subject and previous research papers on road safety, we have reached a conclusion that a significant proportion of available studies center around personality traits as predictors of risky on-the-road behavior (Delhomme, Chaurand, \& Paran, 2012). Why this trend was adopted and what results from it are to a large extent determined by the results of the meta-analysis concerning accidents caused by personal factors by Arthur et al. (1991). The authors identified four categories of these determinants: personality, cognitive resources, information processing, and demographic factors. A relatively large number of papers dealing with a driver's personality have focused on locus of control (Montag \& Comrey, 1987; Warner, Özkan, \& Lajunen, 2010). It was postulated that external locus of control was related to careless driving and underestimating a potentially dangerous situation. By contrast, internal locus of control was associated with a strong feeling of responsibility and higher levels of control over one's actions. Yet, studies that explore this problem indicate that additional determinants modeling the above-mentioned relations are also present (Özkan \& Lajunen, 2005). For example, a study using the Multifactorial Scale of Locus Control documented a relation between a driver's aggressive behavior and his internal locus of control (Özkan \& Lajunen, 2005). The discrepancies between the results of various studies can be explained by the fact that different methodological approaches are adopted to define dangerous on-the-road behavior. It can therefore be assumed that internal orientation is related to consciously undertaking dangerous actions characterized by aggressiveness, while having external orientation is linked to non-intentional behavior, such as underestimating situations on the road and lack of appropriate caution (Schulz, 1976).

Similarly, the results of research studies on drivers' behavior and basic personality dimensions classified in a multifactorial structure as an index of five fundamental and stable dimensions encompassing various human personality traits - remain inconclusive. These dimensions include: extraversion, neuroticism, agreeableness, openness and con- scientiousness (Wontorczyk, 2011). Several studies revealed a positive correlation between fatality rate, neuroticism and extraversion. However, Kirkcaldy and Furnham (2000) as well as Lajunen (2001) observed opposite relations. A negative correlation was also found between agreeableness and a tendency towards risky on-the-road behavior. Data regarding the remaining two dimensions - openness and conscientiousness - are ambiguous and inconclusive (Wontorczyk, 2011).

A vast majority of studies on the relation between risky traffic behavior and personality are centered around the sensation seeking dimension (Delhomme et al., 2012; Garrity \& Demick, 2001); most of them revealed a positive correlation between these variables (Dahlen, Martin, Ragan, \& Kuhlman, 2005; Dahlen \& White, 2006). Also, risk levels determined by personality traits as well as by risk acceptance (closely related to temperamental attributes and need for stimulation) turned out to be important predictors of risky behavior among drivers (Makarowski, Peplinska, \& Nowopolski, 2010; Cybulski, Strzelecki, Grzymisławska-Cybulska, Głowacka, \& Mojs, 2014). Makarowski et al. (2010) found significant relations between one's level of need for stimulation, risk acceptance, prevalence of arousal processes, and aggressive (Farnicka \& Grzegorzewska, 2015), hostile driving style. A relatively small number of studies in the field of transport psychology focus on drivers' temperamental traits and their influence on the potential tendency to engage in risky behaviors. In this subgroup of examinations, a vast majority of research studies have been limited to impulsiveness (Burns \& Wilde, 1995). For example, Beirness (1993), Jonah (1990) and Owsley, McGwin and McNeal (2003) found a positive correlation between risky behavior among drivers and their impulsiveness. There are also studies showing that a lower level of reactivity and a higher level of activity can predispose to risk behaviors and dangerous road situations (Odachowska, 2012; Odachowska \& Ścigała, 2012; Dykas \& Terelak, 2014).

In the face of all this, it is clear that studies exploring relations between drivers' declared values and their risky traffic behavior are insufficient. Which values are declared to be most important in one's life and how they translate into one's behavior are issues that are associated with personal characteristics, such as personality or temperament, as well as with one's social environment. A significant positive correlation was found between drivers' dangerous behavior and instrumental values (such as hedonism, achievement and power in Schwartz's classification), along with a negative correlation between one's driving style and conservative values - including conformity, traditionalism and security (Wontorczyk, 2011). 


\section{OUR STUDY}

Having reviewed the literature and studies carried out previously, we were prompted to define comprehensively what dangerous traffic behavior is. We wished to take into account additional aspects, such as the number of road collisions, tickets for flouting road rules and experiences of driving under the influence of alcohol or drugs. On the other hand, it encouraged us to take a closer look at personal predictors of dangerous behavior, such as socio-demographic variables, but also sensation seeking, locus of control, need for risk and risk acceptance, declared values, self-esteem and temperamental variables. Previous studies include only selected areas of determinants, not their interrelatedness.

The aim of this study was to search for personal determinants of risky traffic behavior and socio-demographic determinants of these relationships, i.e. gender, duration of having a driving license, education and age, in a holistic sense. Results of previous research studies, as noted above, suggest that predictors of dangerous traffic behavior include internal locus of control, sensation seeking, need for risk and risk acceptance, high self-esteem, low reactivity combined with high endurance and activity (which determines high need for stimulation), as well as declaring hedonistic values to be important in one's life (hypothesis 1). Moreover, we assumed that the above-mentioned demographic variables constitute significant determinants of the observed relationships. It was expected that all these assumptions concerning predictors of risky behavior would be true to a larger extent for young persons, males, individuals with higher education and short driving experience (hypothesis 2). These assumptions were based on the analysis of accident rates in Poland, where most perpetrators of fatal accidents are characterized by such a socio-demographic profile, but also on scientific research that has addressed this issue (Bener et al., 2008).

\section{PARTICIPANTS AND PROCEDURE}

\section{PARTICIPANTS}

Given the research assumptions, the participants had to be specifically selected. The sampling method aimed at forming a group of so-called dangerous drivers. The classification criteria were collected in surveys and included: number of road traffic accidents (with fatalities or injured), number of collisions, number of traffic tickets (among others, for speeding or reckless overtaking), and instances of driving under the influence of alcohol or drugs. Only non-professional drivers were considered as potential participants; the procedure excluded professional drivers as these are obliged by Polish law to regularly undergo psychological tests - whoever poses a threat to other road users is eliminated in the process of this assessment. Based on accident rates as well as on long-term practical experience as transport psychologists that some of the authors of this paper have, an assumption was made that professional drivers' driving culture is significantly different from that of the amateur ones and therefore including the former group in the study could be an important confounding factor. Eventually the study examined a total of 380 persons aged between 19 and $61(M e=24)$, who complied with the above-mentioned assumptions and were selected after analyzing a larger group of drivers (1217 persons). As many as $71 \%$ of the participants were female ( $29 \%$ men), $44 \%$ of all participants were married and $31 \%$ had children ( $17.10 \%$ one child, $11.30 \%$ two children; $2.60 \%$ three or more). The majority of all participants had higher education $(57 \%)$. The period of having a driving license ranged between 1 and 47 years $(M e=5)$. All the examined persons, however, were active drivers, and their annual mileage ranged from 15000 to 20000 kilometers. The research was voluntary, unpaid and was carried out among amateur drivers - graduate students, post-graduate students and employees of a corporation in Gdansk. None of the persons in this study had taken part in a re-education course for drivers.

\section{PROCEDURE}

The study was carried out in 2013 and 2014, and the participants were accessed directly. The above-mentioned criteria were used to decide whether a given individual can be classified as a dangerous driver. Moreover, taking our research assumptions into account, we decided to monitor the demographic variables described above with a specially designed survey.

\section{MEASURES}

In order to verify the assumed research hypothesis, a battery of research tools measuring personality and temperamental variables was adopted.

\section{FCZ-KT Formal Characteristics of Behavior - Temperament Questionnaire}

FCZ-KT Formal Characteristics of Behavior - Temperament Questionnaire (Strelau, 2006; Zawadzki \& Strelau, 2010) is based on the Regulative Theory of Temperament (RTT); this theory is currently considered to be the most mature one in examination of drivers. The tool consists of six subscales: 1 ) briskness (a tendency to react rapidly, to keep a high pace of performed activities and to shift behavior easily in 
response to changes), 2) perseveration (a tendency to repeat and continue an action after the stimulus that originally triggered the behavior ceased to operate), 3) sensory sensitivity (the ability to detect and react to stimuli of low stimulative value), 4) emotional reactivity (a tendency to react to emotion-generating stimuli, and manifested as high emotional sensitivity and low emotional endurance), 5) endurance (the ability to tolerate strong stimulation; resistance to fatigue and pain), and 6) activity (a tendency to engage in behavior of high stimulative value; also: behavioral exploration of one's environment to find the most suitable stimulation possible). The reliability index measured with Cronbach's $\alpha$ for particular subscales ranges between .70 and .88 (Zawadzki \& Strelau, 2010).

\section{Rotter I-E Scale}

The Rotter I-E Scale (1966) in the Polish version by Karyłowski (1998) was developed according to Rotter's theory of locus of control and is a general dimension of personality, which describes to what extent individuals believe they can control the events that affect them. The scale measures generalized expectancies for internal versus external control of reinforcements. The tool's reliability according to the Spearman-Brown measure is .79, and Kuder-Richardson coefficient values in three different measurements are $.69, .70$ and .79 respectively.

\section{Risk Acceptance Scale}

The Risk Acceptance Scale by Makarowski (2008) was developed in order to diagnose a tendency to risky behaviors connected with one's health. It was assumed that people with high levels of willingness to take risks are also more prone to undertake unhealthy activities. The Risk Acceptance Scale can be used to estimate one's tendency to take risks by examining one's unhealthy behaviors. The tool's reliability as measured with Cronbach's $\alpha$ is .81 .

\section{Stimulating-Instrumental Risk Inventory (SIRI)}

The Stimulating-Instrumental Risk Inventory (SIRI) by Makarowski (2007) is used to measure one's style of perceiving and interpreting risky behaviors. It distinguishes between two types of risk taking: stimulating risk taking (when risk is seen as a way of providing stimulation, excitement and arousal; it emphasizes activity and searching for experiences by seeking highly stimulating situations, regardless of the outcome and the possibility of loss), and instrumental risk taking (when risk is perceived as an opportunity to achieve a positive outcome; risk taking occurs only when there is a chance of profit; this type of risk requires rational thinking and being focused on the goal). The tool's reliability index as measured with Cronbach's $\alpha$ ranges between .76 and .78.

\section{The Scheler Value Scale}

The Scheler Value Scale adapted by Brzozowski (1995) consists of fifty values grouped into six basic sets: hedonistic, vital, truth, esthetic, moral, and sacral values, as well as four factorial subscales: efficiency and vital strength, endurance, secular sanctity and religious sanctity. The reliability of the Polish version measured with Cronbach's $\alpha$ ranges between .81 and .89 for different subscales.

\section{Zuckerman Sensation Seeking Scale (SSS-V)}

The Zuckerman Sensation Seeking Scale (SSS-V) in the Polish version by Oleszkiewicz-Zsurz (1985) consists of four subscales: 1) thrill and adventure seeking (TAS), 2) experience seeking (ES), 3) disinhibition (DIS), and 4) boredom susceptibility (BS). The internal reliability of these scales measured with Cronbach's $\alpha$ ranges between .56 and .82 (Zuckerman, 1994).

\section{Rosenberg Self-esteem Scale (SES)}

The Rosenberg Self-esteem Scale (SES) adapted by Dzwonkowska, Lachowicz-Tabaczek and Łaguna (2008) measures global self-esteem in adolescents and adults (Sharratt, Boduszek, Jones, \& Gallagher, 2014). The reliability of the Polish adaptation measured with Cronbach's $\alpha$ for different standardization groups - as well as for the entire sample - ranges between .81 and .83 .

Additionally, a questionnaire probing both the drivers' socio-demographic profiles and their on-theroad experiences was used in order to select a target group of examined individuals.

\section{RESULTS}

In our analyses the dangerous driver syndrome is understood as a latent variable that can manifest in four ways: through the number of road collisions, accidents, and traffic tickets, as well as through driving under the influence of alcohol and/or drugs. To operationalize this variable, a principal components analysis with forced extraction of only one factor was carried out; that factor explains nearly $62 \%$ of variability within the dangerous driver syndrome indicators. Values of factor loadings are presented in Table 1. In order to calculate the intensity of the above-mentioned set of attributes, a hierarchical linear regression using the ENTER method was applied. The model posits three levels of explanatory factors: 1) demographic variables (gender, age, educational background, having children, duration of having a driving license, marital status) and personal 
Table 1

Values of factor loadings for the dangerous driver syndrome indicators

\begin{tabular}{lccc}
\hline & $M$ & $S D$ & $\begin{array}{c}\text { Factor } \\
\text { loadings }(\lambda)\end{array}$ \\
\hline $\begin{array}{l}\text { Drunk driving } \\
\text { Number of road } \\
\text { collisions }\end{array}$ & 0.25 & 0.81 & 0.77 \\
$\begin{array}{l}\text { Number of road } \\
\text { accidents }\end{array}$ & 0.08 & 0.28 & 0.81 \\
$\begin{array}{l}\text { Number of } \\
\text { traffic tickets }\end{array}$ & 0.33 & 0.83 & 0.82 \\
\hline
\end{tabular}

Note. $M$ - mean, $S D$ - standard deviation.

variables; 2 ) temperamental variables (briskness, perseverance, sensory sensitivity, emotional reactivity, endurance, and activity), whose impact was analyzed in the context of demographic factors; 3) personality variables (a system of life values, a tendency to undertake risky actions of stimulating nature, i.e. sensation seeking, experience seeking, stimulus seeking, boredom susceptibility, as well as self-esteem, locus of control, tendencies to take and accept risks), whose impact was analyzed in the context of both demographic and temperamental factors.

As shown in Table 1, the results of the conducted analysis reveal that demographic variables explain about $9 \%\left(R^{2}=.86\right)$ of variability of the dependent variable; in addition, temperamental variables increase the predictability of the dangerous driver syndrome intensity by about $20 \%$ (change of $R^{2}=.20$ ), and this result clearly shows that the difference is statistically significant $F(2,346)=47.95, p<.001$. Next, personality variables in the context of demographic and temperamental ones improve the result by $25 \%$ (change of $R^{2}=.25$ ), also making the difference statistically significant: $F(9$, $337)=20.38, p<.001$ ). From the data gathered it follows that the model predicting traits of a dangerous driver which takes into account sets of demographic and personal factors (the latter including temperamental and personality ones) allows one to predict more than $52 \%$ $\left(R^{2}=.52\right)$ of variability of the explained variable.

A detailed analysis (Table 2) reveals that among the demographic variables included in the model (Set 1 ), the following are statistically significant: age $(\beta=.28, p<.001)$, gender $(\beta=.09, p=.031)$ and the duration of having a driving license $(\beta=-.24, p=.014)$; more specifically: age and the male sex correlate positively with the dangerous driver syndrome, whereas the duration of having a driving license correlates negatively with it. The variables marital status, educational status and having children did not influence the dependent variable significantly, and were therefore eliminated from the model. Hypothesis 2 was confirmed only partially. From the data gathered we can conclude that the characteristics of a driver jeopardizing his own safety and the safety of others are most strongly manifested in older men with short driving experience. Among the personal variables of temperamental nature (Set 2), sensory sensitivity and emotional reactivity proved to be significant ( $\beta=-.18, p<.001$ and $\beta=-.11, p=.021$, respectively), and both correlate negatively with the explained variable. Therefore low sensory sensitivity and emotional reactivity levels (which correspond to a greater need for stimulation in everyday life) intensify - statistically speaking - traits characteristic of dangerous road users. Briskness, perseverance, endurance and activity were all excluded from the model, since they were not significant in variation of the dependent variable. Hypothesis 1 was confirmed only partially. Two of the personality variables (Set 3 ) turned out to be significant in explaining the dependent variable. These two, most strongly related with it, were a tendency to be driven by hedonistic values (positive relationship, $\beta=.38, p<.001$ ) and a tendency to be guided by moral values (negative relationship, $\beta=-.38, p<.001)$. Other variables proved to be significant, too: self-esteem (positive correlation, $\beta=.15$, $p=.012$ ), locus of control (negative correlation, $\beta=-.11$, $p=.022$, which means internal locus of control), sensation and adventure seeking (positive correlation, $\beta=.14, p=.051$ ), thrill seeking (positive correlation, $\beta=.13, p=.052$ ), boredom susceptibility (negative correlation, $\beta=-.15, p=.021)$. Finally, accepting risks in everyday functioning $(\beta=.11, p=.031)$, especially risks of a stimulating nature $(\beta=.13, p<.001)$, also turned out to influence significantly (and positively) variation of the dependent variable. It justifies our claim that the intensity of the dangerous driver syndrome, aside from being influenced by demographic and temperamental variables as mentioned before, is also fostered by high self-esteem, a sense of being in control of one's fate, and by living a life driven mainly by seeking pleasure and intense feelings, even if it

Table 2

Parameters of fit of the models along with statistics describing changes of fit

\begin{tabular}{lcccccccc}
\hline Model & $R^{2}$ & Revised $R^{2}$ & $S E$ & Change of $R^{2}$ & $F$ of change & $\mathrm{df1}$ & $\mathrm{df2}$ & $p$ of change \\
\hline 1 & .09 & .09 & .99 & .09 & 11.82 & 3 & 348 & $<.001$ \\
2 & .29 & .28 & .88 & .20 & 47.95 & 2 & 346 & $<.001$ \\
3 & .54 & .52 & .72 & .25 & 20.38 & 9 & 337 & $<.001$ \\
\hline
\end{tabular}

Note. $R^{2}$ - squared multiple correlation; $S E$ - standard error of revised $R^{2} ; F-F$-test of significance of $R^{2}$; df - degrees of freedom; $p$ - level of significance 
Table 3

Regression coefficients for variables included in the hierarchical regression

\begin{tabular}{lccccc}
\hline Predictors & $B$ & $S E$ & $\beta$ & \multicolumn{1}{c}{$t$} & \multicolumn{1}{c}{$p$} \\
\hline Age & .03 & .01 & .28 & 3.87 & .001 \\
Gender (male) & .21 & .10 & .09 & 2.16 & .032 \\
Duration of having a driving license & -.03 & .01 & -.24 & -3.31 & .001 \\
Sensory sensitivity & -.05 & .01 & -.18 & -4.47 & $<.001$ \\
Emotional reactivity & -.02 & .01 & -.11 & -2.35 & .019 \\
Self-esteem & .03 & .01 & .15 & 3.37 & .001 \\
Thrill and adventure seeking & .04 & .01 & .14 & 2.81 & .005 \\
Experience seeking & .04 & .01 & .13 & 2.83 & .005 \\
Boredom susceptibility & -.04 & .01 & -.12 & -2.44 & .015 \\
Locus of control & -.04 & .01 & -.14 & -3.51 & .001 \\
Hedonistic value & .02 & .01 & .38 & 5.98 & $<.001$ \\
Moral value & -.02 & .01 & -.38 & -6.37 & $<.001$ \\
Stimulating risk taking & .02 & .01 & .13 & 2.98 & .003 \\
Risk acceptance & .01 & .01 & .11 & 2.18 & .003 \\
\hline
\end{tabular}

Note. $B$ - unstandardized regression weight; $S E$ - standard error of unstandardized regression weight; $\beta$ - standardized regression weight; $t$ - $t$-test for significance of coefficient; $p$ - level of significance

means transgressing generally accepted moral principles - especially those concerning potential situations in which the health and life of oneself or others may be jeopardized (Table 3).

\section{DISCUSSION}

Our findings lead to a conclusion about a specific socio-demographic and psychological profile of a driver who can be classified as a dangerous one. On the basis of the analysis conducted, the authors found that among socio-demographic variables, gender, age and duration of having a driving license were significant predictors of dangerous behaviors on the road. Therefore, drivers who can pose a real threat while on the road are those men who are advanced in age and at the same time have had their driving licenses for a short period of time (which probably means their driving experience is limited). These results are partially supported by other research studies (Bener et al., 2008) which indicate that is it precisely men and inexperienced people who relatively often pose real threats in road traffic, commit dangerous traffic offenses, and cause traffic accidents more often (Donmez el al., 2010; Odachowska, 2012). The assumptions about the drivers' young age were not confirmed, however (Odachowska, 2012; Odachowska \& Ścigała, 2012; Dykas \& Terelak, 2014). One can only theorize that seniors have higher self-esteem and often inadequate perception of their driving competencies - this may be due to their experiences and successes in other domains of personal life or professional work. These assumptions are evidenced by further analyses which demonstrate that although these variables remain significant, they only explain about $9 \%$ of the observed variability, and they are significantly related to other temperamental and personality factors. Consequently, the second group of predictors of dangerous traffic behavior consists of the following temperamental variables: high levels of risk and stimulation seeking, low level of tolerance to monotony, high self-esteem, internal locus of control, high levels of need for stimulating risk, high levels of risky behavior acceptance, low levels of sensory sensitivity and low levels of reactivity - and in addition, the declared prevalence of hedonistic values over moral ones among drivers. Our findings generally support the initial hypotheses and are consistent with the results of previous studies dealing with the problem in question (Delhomme et al., 2012; Wontorczyk, 2011). Taking risky decisions and engaging in risky on-the-road behavior are fostered by high levels of thrill and adventure seeking, looking for new sensations and experiences, combined with high boredom susceptibility and - at the same time - aversion to routine and anxiously reacting to monotony (e.g. while in traffic jams). Therefore it seems justified to suspect that a driver characterized by this profile will seek extra stimulation, e.g. through speeding, an aggressive driving style or taking unnecessary risks (Delhomme et al., 2012; Garrity \& Demick, 2001). Simultaneously, high levels of boredom susceptibility and intolerance to monotony can foster feelings of anxiety, edginess, irritation and frustration. When these are given vent to, one may be more vulnerable to aggression of others or can 
misinterpret environmental cues, ultimately leading to aggressive behavior (Havârneanu \& Havârneanu, 2012). This type of (often unpredictable) behavior is further promoted by high need for stimulating risk and high risk acceptance (Makarowski et al., 2010), as well as by high self-esteem manifested as an inflated and often inadequate self-assessment of one's driving competence (Schreer, 2002). If this is the case, dangerous driving behavior will include speeding, risky maneuvering or taking risky decisions which pose a real threat to other road users (Bener et al., 2008).

Moreover, we have proven that values declared by drivers - which, among other things, influence their lifestyles - are significant predictors of traffic behavior. In this case, dangerous on-the-road behavior is promoted through preferring hedonistic values over moral ones - this is manifested in acknowledging that possessing things is a value, in pleasure, in deriving joy from life, and at the same time in rejecting values such as kindness, honor, helpfulness and honesty. This set of values favors having expensive, luxurious and fast cars, as well as seeking sensation without considering other human beings - in this case, other road users. The findings are consistent with the results of previous studies on relationships between one's preferred values and traffic behavior (Wontorczyk, 2011). However, reviewing the literature of the problem revealed some gaps, too - evidence of the limited interest that researchers have in this issue. Nevertheless, the available data lead to a conclusion that an individual's declared values constitute a significant predictor of on-the-road behavior and therefore should be further examined.

An intriguing result was obtained in the case of temperamental variables. In view of previous research findings we assumed that a level of reactivity (which determines - among other things - one's functioning style by fueling a high need for stimulation) is an important predictor of dangerous road behavior (Makarowski et al., 2010; Strelau, 2006; Odachowska, 2012; Dykas \& Terelak, 2014). However, apart from this factor, a low level of sensory sensitivity - a potential determinant of low sensitivity to danger signals - also turned out to be a significant predictor of dangerous traffic behavior. This trait may result in ignoring cues important from the point of view of road safety, making wrong decisions, and engaging in truly hazardous situations. And when we consider the fact that these low levels of sensory sensitivity may go hand in hand with a high need for risk, stimulation and experience, as well as with low monotony tolerance and high self-esteem, a clear profile of a dangerous driver appears.

Finally, a significant predictor of dangerous traffic behavior turned out to be one's internal locus of control. These results may confirm that it is reasonable to explore relations between internal locus of control and aggressive behaviors among drivers (Özkan
\& Lajunen, 2006), especially if this variable is accompanied by other above-mentioned personal variables, such as high self-esteem, low levels of boredom tolerance, strong need for sensation and thrill seeking, etc. Therefore, the conducted analyses show the validity of comprehensive research studies encompassing not only locus of control, but also other personality and temperamental variables, which could explain some of the discrepancies arising in this matter and already presented in the introduction to this paper.

\section{CONCLUSIONS}

It can be concluded that both socio-demographic and psychological variables, such as temperament and personality, are significant predictors of dangerous traffic behavior. This behavior is promoted by high levels of sensation seeking, low levels of tolerance to boredom and monotony, high levels of stimulating risk taking and risk acceptance, high self-esteem, internal locus of control, preferring hedonistic values and disregarding moral ones, and finally low levels of sensory sensitivity and reactivity - especially when these traits are demonstrated in older men with short driving experience. Both the study results and our initial assumptions concerning the analyzed relations call for further studies in this field, which should have larger groups of participants (including a larger group of men) and take into account a wider range of socio-demographic variables and other methods of statistical analysis which would allow for an exploration of the moderator and mediator relations that were observed.

Furthermore, it should not be forgotten that each study of this kind can broaden the knowledge and awareness of practitioners and researchers who deal with road safety issues - and thus encourage specific practical and preventive actions aiming to bolster traffic safety, for example in psychological testing of drivers and re-education programs for drivers.

This paper was presented previously during $10^{\text {th }}$ International Conference "Woman in Culture: Gender, Culture \& Migration" held at University of Gdansk, Poland, in March 2015. The conference was co-funded from Norway Grants in the Polish-Norwegian Research Programme operated by the National Centre for Research and Development.

\section{References}

Arthur, W., Barret, G. V., \& Alexander, R. A. (1991). Prediction of Vehicular Accident Involvement: A Meta-Analysis. Human Performance, 4, 89-105.

Bąk, J., \& Bąk-Gajda, D. (2008). Dangerous drivers' behavior in road traffic - reasons, results, prevention Journal of KONES, 15, 15-20. 
Beirness, D. J. (1993). Do we really drive as we live? The role of personality factors in road crashes. Alcohol Drugs and Driving, 9, 129-143.

Bener, A., Al Maadid, M. G. A., Özkan, T., Al-Bast, D. A. E., Diyab, K. N., \& Lajunen, T. (2008). The impact of four-wheel drive on risky driver behaviours and read traffic accidents. Transportation Research Part F, 11, 324-333.

Brzozowski, P. (1995). Skala Wartości Schelerowskich - SWS [The Scheler Value Scale - SVS]. Warszawa: Pracownia Testów Psychologicznych Polskiego Towarzystwa Psychologicznego.

Burns, P. C., \& Wilde, G. J. S. (1995). Risk taking in male taxi drivers: Relationships among personality, observational data and driver records. Personality and Individual Differences, 18, 267-278.

Cybulski, M., Strzelecki, W., Grzymisławska-Cybulska, M., Głowacka, M.D., \& Mojs, E. (2014). Determinanty osobowościowe a drogowe zachowania ryzykowne w pracy kierowców pojazdów uprzywilejowanych transportu medycznego w województwie wielkopolskim [Determinants of personality and risky road behaviors at work in drivers of medical transport vehicles in the Wielkopolska voivodeship]. Medycyna Pracy, 65, 485-496.

Dahlen, E. R., Martin, R. C., Ragan, K., \& Kuhlman, M. M. (2005). Driving anger, sensation seeking, impulsiveness, and boredom proneness in the prediction of unsafe driving. Accident Analysis \& Prevention, 37, 341-348.

Dahlen, E. R., \& White, R. P. (2006). The Big Five factors, sensation seeking, and driving anger in the prediction of unsafe driving. Personality and Individual Differences, 41, 903-915.

Delhomme, P., Chaurand, N., \& Paran, F. (2012). Personality predictors of speeding in young drivers: Anger vs. sensation seeking. Transportation Research Part F: Traffic Psychology and Behaviour, 15, 654-666.

Donmez, B., Boyle, L., \& Lee, J. (2010). Differences in Off-Road Glances: Effects on Young Drivers' Performance. Journal of Transportation Engineering, 136, 403-409.

Dykas, J., \& Terelak, J. F. (2014). Temperamental traits and styles of coping stress in motorcyclists. The Polish Journal of Aviation Medicine and Psychology, 20, 11-18.

Dzwonkowska, I., Lachowicz-Tabaczek, K., \& Łaguna, M. (2008). Samoocena i jej pomiar. Polska adaptacja skali SES M. Rosenberga [Self-esteem and how to measure it. Polish adaptation of Rosenberg's SES]. Warszawa: Pracownia Testów Psychologicznych Polskiego Towarzystwa Psychologicznego.

Farnicka, M. A., \& Grzegorzewska, I. (2015). Intrapersonal correlates of aggression in adolescents: determinants of adopting the role of the perpetrator and the victim. Current Issues in Personality Psychology, 3, 25-35.
Garrity, R., \& Demick, J. (2001). Relations Among Personality Traits, Mood States, and Driving Behaviors. Journal of Adult Development, 8, 109-118.

Havârneanu, G. M., \& Havârneanu, C. E. (2012). When norms turn perverse: Contextual irrationality vs. rational traffic violations. Transportation Research Part F: Traffic Psychology and Behaviour, 15, 144-151.

Jonah, B. A. (1990). Age differences in risky driving. Health Education Research, 5, 139-149.

Karyłowski, J. (1998). Skala I-E Rottera [Rotter's I-E Scale]. Warszawa: unpublished manuscript.

Kirkcaldy, B., \& Furnham, A. (2000). Positive affectivity, psychological well-being, accident-and traffic-deaths and suicide: An international comparison. Studia Psychologica, 42, 97-104.

Krahé, B., \& Fenske, I. (2002). Predicting aggressive driving behavior: The role of macho personality, age, and power of car. Aggressive Behavior, 28, 21-29.

Lajunen, T. (2001). Personality and accident liability: are extraversion, neuroticism and psychoticism related to traffic and occupational fatalities? Personality and Individual Differences, 31, 1365-1373.

Makarowski, R. (2007). Jakie emocje występują podczas pierwszego w życiu lotu szybowcem oraz pierwszego w życiu skoku ze spadochronem? [What sort of emotions do we experience during our first glider flight and our first parachute jump?]. Medycyna Sportowa, 5, 279-284.

Makarowski, R. (2008). Granice ryzyka. Paradygmat psychologiczny [Risk limits. A psychological paradigm]. Cracow: Oficyna Wydawnicza Impuls.

Makarowski, R., Peplinska, A., \& Nowopolski, M. (2010). Psychological aspects of risk and aggression among motorcyclist - "Mad Max" Syndrome. Polish Psychological Bulletin, 41, 74-83.

McKnight, A. J., \& McKnight, A. S. (1999). Multivariate analysis of age-related driver ability and performance deficits. Accident Analysis \& Prevention, 31, 445-454.

Montag, I., \& Comrey, A. L. (1987). Internality and externality as correlates of involvement in fatal driving accidents. Journal of Applied Psychology, 72, 339-343.

Nabi, H., Consoli, S. M., Chastang, J. F., Chiron, M., Lafont, S., \& Lagarde, E. (2005). Type A behavior pattern, risky driving behaviors, and serious road traffic accidents: a prospective study of the GAZEL cohort. American Journal of Epidemiology, 161, 864-870.

Odachowska, E. (2012). Temperament a skłonność do zachowań ryzykownych w ruchu drogowym [Temperamental conditioning of hazardous behavior based on the analysis of drivers]. Transport Samochodowy, 1, 35-51.

Odachowska, E., \& Ścigała, D. K. (2012). Psychologiczne uwarunkowania zachowań ryzykownych w ruchu drogowym na podstawie badań kierow- 
ców [Psychological determinants of risky behaviors on road based on the analysis of drivers]. In: E. Odachowska (ed.), Psychologia zachowań ryzykownych w ruchu drogowym [Psychology of risky behabiors on the road] (pp. 61-168). Warszawa: Instytut Transportu Samochodowego.

Oleszkiewicz-Zsurz, Z. (1985). Adaptacja skali poszukiwania wrażeń (SSS) M. Zuckermana do warunków polskich [Adaptation of Zuckerman's Sensation-Seeking Scale (SSS) to Polish conditions]. Przegląd Psychologiczny, 28, 1123-1128.

Owsley, C., McGwin, G., Jr., \& McNeal, S. F. (2003). Impact of impulsiveness, venturesomeness, and empathy on driving by older adults. Journal of Safety Research, 34, 353-359.

Özkan, T., \& Lajunen, T. (2005). Multidimensional Traffic Locus of Control Scale (T-LOC): factor structure and relationship to risky driving. Personality and Individual Differences, 38, 533-545.

Rimmö, P.-A., \& Hakamies-Blomqvist, L. (2002). Older drivers' aberrant driving behaviour, impaired activity, and health as reasons for self-imposed driving limitations. Transportation Research Part F: Traffic Psychology and Behaviour, 5, 47-62.

Rotter, J. B. (1966). Generalized expectancies for internal versus external control of reinforcement. Psychological Monographs: General and Applied, 80, 1-28.

Schaw, L., \& Sichel, H. S. (1971). Accident proneness. Oxford: Pergamon.

Schreer, G. E. (2002). Narcissism and Aggression: Is Inflated Self-Esteem Related to Aggressive Driving? North American Journal of Psychology, 4, 333-342.

Schulz, R. (1976). Effects of control and predictability on the physical and psychological well-being of the institutionalized aged. Journal of Personality \& Social Psychology, 33, 563-573.

Sharratt, K., Boduszek, D., Jones, A., \& Gallagher, B. (2014). Construct validity, dimensionality and factorial invariance of the Rosenberg Self-Esteem Scale: a bifactor modelling approach among children of prisoners. Current Issues in Personality Psychology, 2, 228-236.

Shinar, D. (1978). Psychology on The Road - the human factor in traffic safety. New York: Wiley \& Sons, Inc.

Strelau, J. (2006). Temperament jako regulator zachowania. Z perspektywy pótwiecza badań [Temperament as a regulator of behavior: After fifty years of research]. Warszawa: Gdańskie Wydawnictwo Psychologiczne.

Szmajke, A. (1992). Osobowość w percepcji i akceptacji zagrożeń [Personality in perceiving and accepting threats]. In: T. Tyszka (ed.), Psychologia i bezpieczeństwo pracy [Psychology and safety at work] (pp. 229-257). Warszawa: Instytut Psychologii PAN.

Szulc, M. (2013). Konsekwencje zdrowotne używania marihuany w świetle badań oraz propozycja ujednolicenia stanowiska psychologów wobec proble- mu legalizacji konopi, sformułowana w oparciu o Kodeks Etyczno-Zawodowy Psychologa [Health consequences of using marijuana in the light of surveys, and the proposal of unifying the stance of psychologists on the issue of cannabis legalization - based on Ethical Principles of Psychologists and Code of Conduct]. Alkoholizm i Narkomania, 26, 381-401.

Thiffault, P., \& Bergeron, J. (2003). Fatigue and individual differences in monotonous simulated driving. Personality and Individual Differences, 34, 159-176.

Treffner, P. J., \& Barrett, R. (2004). Hands-free mobile phone speech while driving degrades coordination and control. Transportation Research Part F: Traffic Psychology and Behaviour, 7, 229-246.

Warner, H. W., Ozkan, T., \& Lajunen, T. (2010). Can the traffic locus of control (T-LOC) scale be successfully used to predict Swedish drivers' speeding behaviour? Accident Analysis \& Prevention, 42, 1113-1117.

Waszkowska, M., \& Garczarek, A. (2008). Kim jest niebezpieczny kierowca? [Who is a dangerous driver?]. In: W. M. Horst, \& G. Dahlke (eds.), Bezpieczeństwo na drogach - edukacja i diagnostyka kierujacych pojazdami [Road safety - education and diagnostics of vehicle drivers] (pp. 239-248). Poznan: Wydawnictwo Instytutu Inżynierii Zarządzania Politechniki Poznańskiej.

Watling, C. N., \& Freeman, J. (2011). Exploring the theoretical underpinnings of driving whilst influenced by illicit substances. Transportation $R e-$ search Part F: Traffic Psychology and Behaviour, 14, 567-578.

Wontorczyk, A. (2011). Niebezpieczne zachowanie kierowców. Psychologiczny model regulacji zachowań w ruchu drogowym [Dangerous behaviors in drivers. Psychological model of the regulation of behaviors in the road traffic]. Cracow: Wydawnictwo Uniwersytetu Jagiellońskiego.

Wyszomirska-Góra, M. (2013). Psychologiczne determinanty wyboru środka transportu w codziennych podróżach miejskich [Psychological determinants of choosing means of transport in everyday municipal travels]. Transport Miejski i Regionalny, 1, 4-9.

Zawadzki, B., \& Strelau, J. (2010). Formalna charakterystyka zachowania - Kwestionariusz Temperamentu (FCZ-KT) [Formal Characteristics of Behaviour-Temperament Inventory (FCB-TI)]. Warszawa: Pracownia Testów Psychologicznych Polskiego Towarzystwa Psychologicznego.

Zuckerman, M. (1994). Behavioural Expressions and Biosocial Bases of Sensation-Seeking. Cambridge: Cambridge University Press. 